\title{
Rehabilitation and Reintegration Policies of Children Victims of Criminal Action in the Children's Criminal Jurisdiction System
}

\author{
${ }^{1}$ Ani Purwati ${ }^{1},{ }^{2}$ Fifin Dwi Purwaningtyas, ${ }^{3}$ Jumali Sapta Agung \\ ${ }^{1}$ Wijaya Putra University, Faculty of Law, Department of Law, Surabaya, Indonesia \\ ${ }^{2}$ Wijaya Putra University, Faculty of Law, Department of Psychology, Surabaya, Indonesia \\ ${ }^{3}$ East Java Provincial Government, Indonesia
}

Submitted: 2021-04-20 • Accepted: 2021-06-27 • Published: 2021-08-18

\begin{abstract}
This research examines the rehabilitation and reintegration policies of child victims in criminal justice system in Indonesia. The methodology used in this research is a mix methodological approach between law and psychology with a conceptual approach and a statute approach to analyse the deficiency of current legislation. Cost-benefit analysis (CBA) was also used in determining the calculation of the punishment for child victims by considering the national regulation. The results showed that legal system on social rehabilitation and reintegration of child victims is regulated in international instrument of Child Rights Convention, Beijing Rules, and Tokyo Rules, which are integrated within the national law of child's protection and child's criminal justice system. Moreover, the application of victim rehabilitation and reintegration within the perspective of cost-benefit analysis determines the punishment classification, such as the heavy punishment with small arrest probability, while the light punishment has bigger arrest probability.
\end{abstract}

Keywords: restorative justice, child victims, Cost-Benefit Analysis (CBA), rehabilitation, social reintegration.

\section{Graphical abstract}
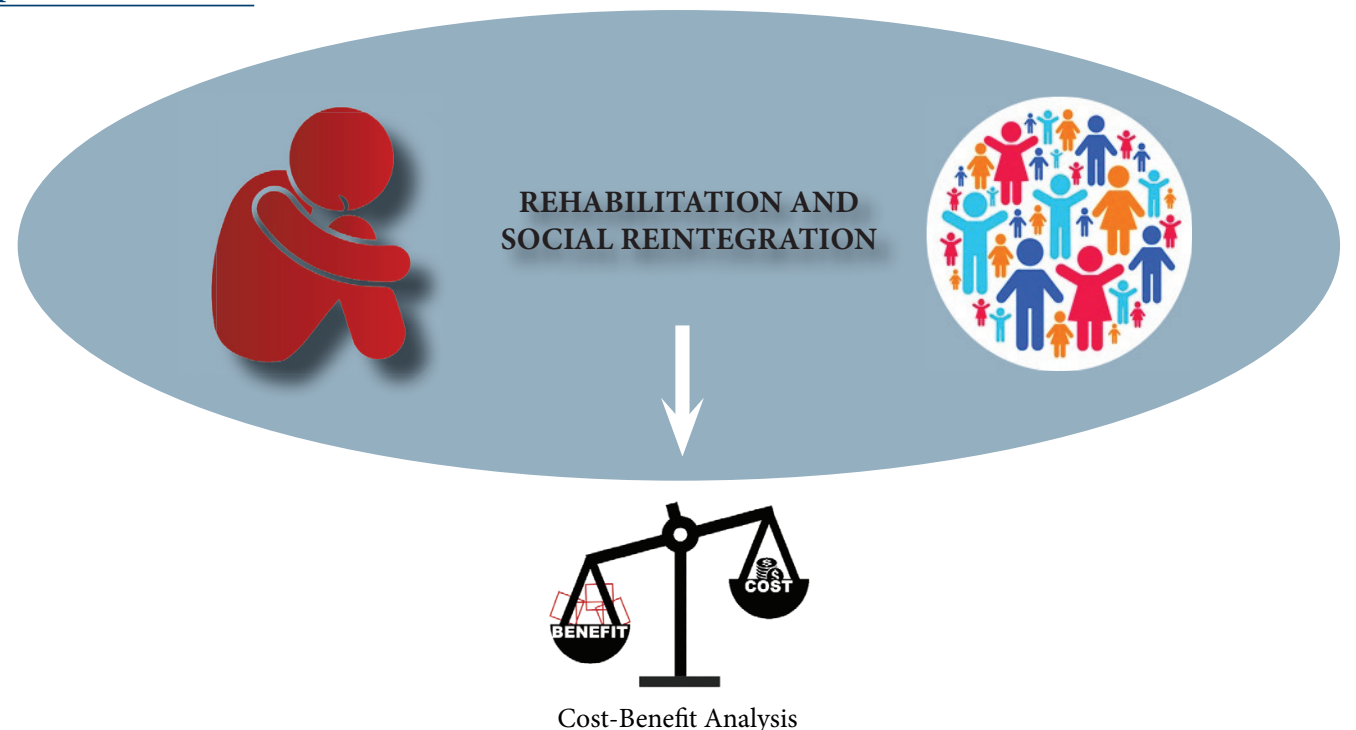

1 Corresponding author: aniipurwati198275@gmail.com

Citation: Purwati, A., Purwaningtyas, F. D., \& Agung, J. S. (2021). Rehabilitation and reintegration policies of children victims of criminal action in the children's criminal jurisdiction system. NBP. Nauka, bezbednost, policija, 26(2), 53-61. ISSN 2620-0406 https://doi.org/10.5937/nabepo26-31914 


\section{INTRODUCTION}

There are at least 4,116 cases of violence against children recorded by the Ministry of Women's Empowerment and Child Protection in 2020 indicating that there are a total of 12,855 cases in Indonesia as an indicator of the weak protection of children as victims of crime (Kamil, 2020). In East Java, the total number of children victims were 2,498 in 2018 and increased in 2019 for 2,963 children, which consists of children who face the law, children as victims, children as perpetrators, children as witnesses of raping case, sexual abuse, theft, assault, murder, narcotics, murder, or gambling, then children with HIV disease, children who experienced a mistreatment, children as victims and children with disabilities. Several weaknesses in the implementation of legal regulations and cost benefit application have been found, such as in handling the case of under aged victims that still ignore the fulfilment of the visum et repertum (Medico legal report) as trial evidence (Article 13/1 of Criminal Procedure Code). The government and the local government are also committed to resume the social work rehabilitation of the under aged victims and reintegrate them into society but in turn, they are still subjected to the processing constraints. However, this processing method has not been well integrated by both Litmas Bapas report (society research report) and law enforcement officers (police, prosecutors, and courts) in their administrative procedures. Technically speaking, Execution of Decisions that have permanent legal force (inkracht) towards the child as the victim puts forward not only the imprisonment and the supervision of the child within the Child Welfare Protection Agency (LPKA), but also the assessment value, both substantive and non-substantial (traumatic) value, of restoration losses in the form of rehabilitation compensation and compensation for minor victims (Huda, 2006).

The weakness of the implementation of children social rehabilitation and integration defunctionalisation is that the person cannot properly perform his social functions in social life. Practically, the underage victims required a long process to restore the victim's social function, just like rearranging the mental state of a child; therefore, many changes are required. During the process, a professional psychologist should be asked for consultation. If an emergency occurs (for example, the child is pregnant or the family finds that the child is being sexually abused from relatives or family), a social protection centre should be constructed. Child protection and safety are the main focal points, several social workers experience difficulties of handling the cases if their family and relatives reject the existence of sexual abuse because it is considered as disgrace to the family, thus, the child protection or LKSA (in Indonesia Lembaga Kesejahteraan Sosial Anak) or Child Welfare Institutions become a reference for placing the child in a certain place until the child recovers, or gives birth to the child (Suryani \& Hardiati, 2016). The institution will be able to provide education when the child wants to remain at the LKSA.

The individualization of each victim can be truly felt by social workers since every child has his/her own characteristics, including the social environment of family, education, friends and others. Thus, the rehabilitation and integration process cannot be made by the same curriculum during the same period using the same service standards. Likewise, when an institution has its own local characteristics according to its human resources management capacity and its facilities, the institution tends to move the victims from one place to another.

Another weakness is that the victims often have multiple cases that follow after their legal handling and social rehabilitation have been completed. Moreover, there will be other dif- 
ficulties if the children do not have a family, are rejected by their family, have an inharmonious relationship with their family, broken home, or are far from their family (their parents work abroad) (Herlina \& Apong, 2004). Distance also becomes the weakness since the social worker should check from home to home and ask about the victim's condition continuously. The process of social work practice that is carried out by social workers for social rehabilitation and reintegration cannot be done individually. Social workers should be able to place the mandate and role for every party to maximize the performance. Through diverse solutions, criminals, victims and society are legally protected, forgiven and compensated (Wahyudi, 2011). Perpetrator is able to realize behavioural improvements and alternative forms of sanctions that guide individual recovery and behaviour improvement (Angkasa et al., 2009). Rehabilitation policy and social reintegration of victims in the cost-benefit analysis (CBA) calculation method is done through the concept of legal psychology with its focus on the balance between trial and post-trial psychology, social, vocational rehabilitation and medical rehabilitation. This study discussed two issues, namely, legal arrangements and the implementation of rehabilitation and reintegration policies for victims of crime. The development of the concept of "child recovery clinic" to contribute on the calculation of immaterial losses, the value of criminal losses and the social services reports are included as a part of the reformation of the criminal justice system of Law Number 11/2012 concerning the juvenile criminal justice system. Therefore, this study has objectives to analyse the social rehabilitation and reintegration of the protection of child victims in criminal justice system in Indonesia.

\section{METHODOLOGY}

This study used descriptive qualitative methodology along with cost benefit analysis (CBA) with law and psychology within the statute and conceptual approach. Descriptive qualitative methodology is a type of research where the results are not obtained through quantification procedures, calculations, or other means that use numerical measures (Gunawan, 2013). CBA is used to compare the psychology, social, vocational recovery and medical rehabilitation either in pre-trial, trial and post-trial period. CBA is used to determine criminal policy to balance the national regulations, since it emphasizes the importance of profit and loss. The use of both statute and conceptual approach are to analyse the weaknesses of the current legislation, such as centralized legal protection for underage victims of the fulfilment of (informal) restorative justice evidence. This type of research includes normative juridical research. First, statutory approach examines and analyses the consistency and suitability of laws related to the implementation of rehabilitation policies and reintegration of children as victims in international and national legal regulations (Marzuki, 2016). Second, the conceptual approach examines and analyses the concept of implementing the rehabilitation and reintegration of children as victims within the CBA method (Marzuki, 2016). The data were collected through library research, such as journals, books, internet and others. To achieve the objective of the research, legal psychology research was also used to obtain empirical data, especially in the context of tracing the implementation of child rehabilitation policies and social reintegration of children as victims at the scope of investigation, prosecution, court and post-recovery juvenile justice.
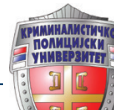

(1)

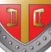

NBP. Nauka, bezbednost, policija 


\section{RESULTS AND DISCUSSION}

The facilities of social rehabilitation and the management of children's behaviour by the law, both perpetrators and victims, should be carried out by formal and post-trial rehabilitation program that include psychological, social, vocational recovery and medical aspects of rehabilitation for underage victims. The success scale of restorative program (recovery of victim's children) by psychosocial assistance of underage victims and their families can help children and families to find the problems within the required assessment method and assist the victims' problems such as stigma, personal and social independence and trauma. Regulations for the Rehabilitation and Integrity of Children as Victims of International Instruments include the following (Muladi, 2002):

a) Declaration of Human Rights, resolution Number 217A (III) Children as victims are regulated under the Convention of Children's right, Article 13 (legal jurisdiction for examining children abuse), article 14 (the legal system on the fulfilment of compensation of victim abuse), article 15 (statement of victims as evidence of trial);

b) International Convention on Economic, Civil, Political and Cultural Rights Article 7 (legal protection did not apply to physical abuse but mental abuse), article 10 (special measures to protect all children and adolescents without discrimination);

c) Convention on the Rights of Child Resolution Number 109/1990 is regulated within Article 2 (handling of witnesses and victims of non-discrimination), Article 12 (numbers 1 and 2 of the state guarantee freedom according to the weight of the child's age and maturity at the same time the right to have their opinions heard in court either directly or represented by an institution in accordance with national legal regulations), Article 19 (protection of physical abuse, mental abuse, exile, exploitation of children, adults, families and institution) and article 39 (the country takes remedial steps of physical and spiritual recovery and the reintegration of children as victims of every kind of exile, exploitation, abuse, torture, and inhuman punishment);

d) Beijing Rules number 11 (guideline for juvenile justice system). The State facilitates the policies of social programs implementation with temporary supervision, guidance, restitution and compensation of victims;

e) CBA considerations are regulated by Tokyo Rules number 8 which regulates the disposition of the punishment by considering the rehabilitation of perpetrator and the interests of victim, then reinforced in 8.2 by imposing economic sanctions and monetary penalties such as penalty payment, compensation to victims and Article 9 of Law Number 11/2012 concerning the Criminal Justice System for Children.

The Policy for Rehabilitation and Integrity of Children as Victims of National Instruments:

a) Law Number 39/1999 concerning Human Rights is regulated by Article 39/1 (legal protection of children against all physical, mental, educational, bad treatment and sexual abuse is responsible for the parenting and guiding), 39/2 (implementing further punishment or penalty if the parents, guardians and other parties commit an act that was regulated in article 39/1);

b) Law Number 23/2002 concerning Child Protection regulated in Article 63/3a (protection of children specifically for victims of criminal acts as referred in paragraph 1 through rehabilitation efforts from the inside institutions and outside institutions), Article 64 
paragraph 1 and 2 (confidentiality on the identity of victims from the offline or online media, whether it comes from names, address, face, and identity of children as victims, witnesses, parents), article 23 regarding the right to be accompanied at every examination by parents, trusted persons, social workers within the exception of parents as suspects), Article 63/3 (to obtain any information on case developments);

c) Law Number 11/2012 concerning the Criminal Justice System for children, guarantees of safety and sense of security, Article 19 (protection of the victim's identity through the mass media to avoid labelling), Article 64/2 (protection for witnesses and expert witnesses from physically, mentally, and socially abused), Article 90/1 (children of victims and witnesses have the right to progress the medical and social rehabilitation efforts institutionally and outside the institution), Article 91 paragraphs 1, 2, 3 (considerations or suggestions for social advisers, professional social workers, welfare and law enforcement officials provide protection in the form of social reports or assistance measures to hospitals or child welfare protection institutions), Article 91 (protection of social homes for victims/witnesses);

d) Law No. 13/2006 concerning witnesses and victims protection regulated by Article 3 (the principle of protection for witnesses and victims, including respect, sense of security, justice, non-discrimination, and legal certainty), Article 4 (protection of security sense in judicial process), Article 5 letters a to $\mathrm{m}$ (the rights of victims: protection of family security, property, and freedom from threats that will be given and determine the form of protection, get a translator, information on developments in cases and decisions, new identity and residence, transportation costs and temporary living assistance until the end of period);

e) Law No. 11/2009 concerning National Welfare regulated by Article 5 paragraph 2 letter $\mathrm{G}$ (social administration against the act of violence, exploitation and discrimination), protection of social rehabilitation Article 7 paragraphs 1,2 and 3.

The reformation of criminal law that places rehabilitation and social reintegration of victims, families and communities as a form of restoration to their original state related to the value of restorative justice, includes (Muladi \& Arief, 1998):

a) Social Policy: efforts to address social problems in national purposes. The problem of children as perpetrators and victims should be synchronized based on the quality of decision and the victim's psychological report on the assessment of post traumatic syndrome disorder (PTSD) and Correctional Institution report for perpetrator (needs assessment for external and internal delinquency indicators);

b) Criminal Policy: Efforts to overcome the problem of perpetrators, victims, and the society that have been diversified, however in the constitution of juvenile criminal justice system it is standard that diversion is carried out only once, thus, there should be an evaluation mechanism for the effectiveness of crime prevention against Psychological Report of Victims and correctional institution to carry out any recovery;

c) Law Enforcement Policy: carrying out legal reforms in judicial review of Juvenile Criminal Justice System Law and Standard Operating Procedures in calculating the program for social rehabilitation and reinterpretation of crime victims.

However, diversion cannot be implemented for children who did frequent criminality or heavy criminality (Ernaningsih et al., 2017). The application of a victim protection for the 
benefit of the analysis approach to legal regulations and aspects of medical rehabilitation calculates the costs and benefits of material and immaterial losses within the (CBA) through the calculation of the benefit cost by direct crime and budget prevention (insurance for victims of mental health services, compensation for job losses, death costs, legal advisor claim and consequences labelling cost) (Dossetor, 2011). The classification of the cost benefit concept study design on handling and overcoming a crime, according to Martin and Bradley (1964, cited in Cohen, 2000), has function to calculate tangible costs (medical costs, costs of lost wages, court, treatment costs for care and prison services) and intangible costs (monetary calculation of victim recovery costs). The theory of economic approach to the criminal aspect which is called decision theory by Tsebelis (1989) and the game theory by Becker (1968), is help to reduce the probability of police in tackling crime. It is different with Becker (1968, cited in Ibnu Abbas \& Maytandi, 2020), who said that any attempt to increase the probability of conviction or the severity of punishment or both would reduce the potential offenders to embark on offending behaviour, Tsebelis (1989, cited in Ibnu Abbas \& Maytandi, 2020) argued that the law and the policy do not affect the potential offenders to commit crime. Thus, alternatives policies are needed (Pradiptyo, 2011), such as:

a) To determine the calculation of the classification on severe penalties with a small probability of arrest (the heavier a penalty borne by taxpayer, the higher penalty payment required);

b) To determine a light sentence, but the probability of arrest is quite risky.

The Economic Analysis of Law as an economic approach to law is needed to make a regulation of legal products of crime, perpetrators, victims, and society that can be seen from the characteristic, ability, quality, and precision on the preparation of legal product progressively, effectively and efficiently. Several principles for analysing the economics in legal terms include:

a) Principles of Equilibrium Composition

b) Emphasize on this principle and the disparity of rationality towards definitions, perceptions of interests and objectives which are basically divided into two criteria, definitions that have criteria for the interests of people and a country condition. Gaps in regulations and legal provisions are prepared and promulgated, it starts from the definition that there is a gap in rationality, and enforcement does not become efficient, and there is no balance value for common goals.

c) The Gap-Filing Principle

d) This principle is emphasized on the participation of law enforcement officers and law users in realizing and implementing the provisions of law. Within the efficient legal product, it is able to contain all legal provisions in an explicit, understandable, and accessible manner. It explicitly contains the provisions of prohibitions, permissions and exceptions.

e) Principles of Hypothetical Bargains

f) The principle describes the benefits that have flexibility of meaning such as profit (monetary and non-monetary), benefits, advantages, gains, improvements. Quite economical, when a legal provision is enacted or enforced, it is used by legal subjects. This principle emphasizes the effectiveness of legal provisions as supporting tool related to the substance supported by consistency and stability by the consideration of responsiveness. 
Responsiveness considers that legal subject is familiar with a regulation and legal provisions and factual understanding, able to achieve the objectives of enforcement.

g) Correlated Productive Principles

h) This principle emphasizes the level of productivity of legal arrangements through the legal awareness increase of every level in society regarding the existence of legal sanctions against any legal deviation. Law enforcement does not exist in legal sanctions, but exist in the provision of laws and legal consequences. In applying the meaning of legal objectives achievement, it includes:

a) To reduce the tendency to abuse legal provisions;

b) To reduce the negative effects of illegal acts;

c) To strengthen the influence of punishment in mind (full awareness) as to reduce the report of offenders;

d) To improve the quality of difficulties to escape from legal sanctions;

e) The assessment of compliance and protection of those who comply with the law.

The assessment of cost benefits for the prevention and overcoming the juvenile crime is adjusted to the operational standards of each institution in juvenile criminal justice system that is regulated by the Law Number 11/2012 concerning that the juvenile criminal justice system is technically regulated. Minister of Empowerment regulation from the State Minister for Women's Empowerment and Child Protection Number 1/2010 concerning Minimum Service Standards for Integrated Services for Women and Children, the Decree from the Minister of Law and Human Rights Number M.HH-03 was carried out by the Ministry of Law and Human Rights.

The application of medical, social, psychological rehabilitation of work (Vocational Rehabilitation) for the handling of crime victim is carried out related to the report on the implementation of child case response assistance by social workers which includes: child's identity, case description, condition of a child and the parents, the process and results of case observation, follow-up plans and recommendations, legitimized notes by the head of local social services and social workers. The rehabilitation and reintegration policy program is adapted to assist the child victims as medical rehabilitation cluster carried out by general health observations and special therapy, social rehabilitation programs advance on the nursing system, community-based non-nursing systems provided by the assistance of voluntary social workers that comes from village community resilience institution, social cottage systems (social settlements for physical re-functionalization, mental and social development), vocational rehabilitation to train the independence and skills of job training.

\section{CONCLUSION}

Legal arrangements related to the social rehabilitation and reintegration of children as crime victims are regulated in the international instrument regulations of the Child's Rights Convention, the Beijing Rules, and the Tokyo Rules which are integrated in the national Law of Child Protection and Child Criminal Justice System. The evaluation of rehabilitati- 
on and reintegration policies deficiency is by maximizing re-functionalization of victims' social protection shelters and reversal mechanisms of service providers, law enforcement officials, social workers, families, and social institutions and the budget support are used to maximize the performance. The application of rehabilitation and reintegration of child victims in the perspective of CBA, which has been considered with the national regulation, is help to calculate and classify the punishment. The classification is divided into heavy penalties with small probability of arresting (the heavier a penalty by the taxpayer, the higher amount of penalty for paying fines) and light penalties with the probability of arresting is quite high.

\section{ACKNOWLEDGMENTS}

All authors contribute to the renewal of regulations on the protection of children's rights as crime victims as a prototype with a cost benefit analysis approach in Indonesia.

\section{REFERENCES}

Angkasa, A., Hanadi, S., \& Setyadi, M. B. (2009). Model Peradilan Restoratif dalam Sistem Peradilan Anak (Kajian tentang Praktik Mediasi Pelaku dan Korban dalam Proses Peradilan Anak di Wilayah Hukum Balai Pemasyarakatan Purwokerto). Jurnal Dinamika Hukum, 9(3), 186-204. http://dx.doi.org/10.20884/1.jdh.2009.9.3.230

Cohen, M. A. (2000, July). Measuring the costs and benefits of crime and justice. Measurement and analysis of crime and justice: Criminal justice (Vol. 4, NCJ 182411). U.S. Department of Justice.

Dossetor, K. (2011). Cost-benefit analysis and its application to crime prevention and criminal justice research. Technical and background paper series no. 42. Australian Institute of Criminology. https://www.aic.gov.au/publications/tbp/tbp42

Ernaningsih, W., Novianti, V., \& Murty, T. (2017). Implementasi Rehabilitasi dan Reintegrasi Anak Pelaku Tindak Pidana pada Lembaga Pembinaan Anak di Provinsi Sumatera Selatan. Sumber Cahaya, 24(3), 4891-4903. http://dx.doi.org/10.28946/sc.v24i3\%20 Sep\%202017.81

Gunawan, I. (2013). Metode Penelitian Kualitatif: Teori dan Praktik. Bumi Aksara.

Herlina, H., \& Apong, A. (2004). Perlindungan Terhadap Anak Yang Berhadapan Dengan Hukum: Manual Pelatihan untuk Polisi. POLRI dan UNICEF.

Huda, C. (2006). Dari Tiada Pidana Kesalahan Menuju Kepada Tiada Pertanggungjawaban Pidana Tanpa Kesalahan. Prenada Media.

Ibnu Abbas, M. H., \& Maytandi, A. (2020). Game theoretical analysis of corruption on the road in Indonesia. KnE Social Sciences, 4(7), 23-37. https://doi.org/10.18502/kss.v4i7.6840

Kamil, I. (2020). Kementerian PPPA Catat Ada 4.116 Kasus Kekerasan Anak dalam 7 Bulan Terakhir. Kompas.Com. 
Marzuki, P. M. (2016). Penelitian Hukum Edisi Revisi. Kencana.

Muladi, M. (2002). Beberapa Aspek Kebijakan Penegakan dan Pengembangan Hukum Pidana. Citra Aditya Bakti.

Muladi, M., \& Arief, B. N. (1998). Teori-Teori dan Kebijakan Pidana. Alumni.

Pradiptyo, R. (2011). Penegakan Hukum dan Pencegahan Tindak Kejahatan dalam Tinjauan Ilmu Ekonomi. Universitas Gadjah Mada.

Suryani, S., \& Hardiati, E. (2016). Peran Sakti Peksos dalam Pendampingan Program Kesejahteraan Sosial Anak. Jurnal PKS, 15(1), 65-76.

Wahyudi, S. (2011). Implementasi Ide Diversi dalam Pembaruan Sistem Peradilan Pidana Anak di Indonesia. Genta Publishing. 
